\title{
Construction of Responsibility Mechanism in Public Services
}

\author{
Haitian LIU \\ Department of Political Science, National Taiwan University, Taipei \\ Dalian University of Technology,Dalian
}

\begin{abstract}
Public service is the foundation of human dignity and well-being in modern society, and also the main functions of modern government and the main areas of modern society. The development level of public services is a fundamental standard to measure responsible quality and responsibility of modern government. There are some plights in China's public service responsibility mechanism, so here we propose some countermeasures to improve the responsibility mechanism in public services.
\end{abstract}

Keywords- Public Service; Responsibility Mechanism; Localization Innovation

\section{Public SERVICE RESPONSIBILITY MECHANISM}

\section{A. Theory}

Public service is not unique to modern society, because it can be traced back to the ancient righteousness behaviors of civil society and religious organizations. Necessity and rationality of public service activities mainly depend on moral values and charity, government and citizenship, pursuit of social cohesion, and purposes to supply the demand for economic. However, the main reason is relationship between the citizen and the government. On the one hand, citizens transfer some certain rights and do corresponding obligations for their country; on the other hand, government should bear the responsibility to protect the civil right related to the production and development. Public service is the most concentrated expression of this relationship. As can be seen from it, good public service is the government and the citizen comprehensive efforts results of good relationship of government and citizens and a series of effective system. In general, the level of public service is the basic standard to measure modern civilization degree and the citizens' happiness index.

The traditional view is that, Public service is a generic term of labor behavior when government agencies and their staff meet the public needs and provide public goods. It mainly includes three aspects: Basic public services can only be provided by the government, mixed natural monopoly public service and public services provided by the private sector under the control of the government. Actually, such definition of public service has great limitations, because it also needs to consider the characteristics of demand side. Therefore, to grasp the structure of public service, we need to comprehensively consider the provider body and demander body of public service and the involved fields. Establishment of the system, where participants are responsible for each other, is an important prerequisite for the success of public service. Responsible for each other's accountability mechanism mainly include four kinds: government - citizen expression mechanism, provider - producer contract mechanism, citizen - producer customer power mechanism and producers internal governance mechanisms. It not only needs to establish responsibility mechanisms, but also needs sound system support and index system.

B. Value

A sound public service responsibility mechanism not only benefits the general public but also relies on them. About how a good mechanism comes into being, the British philosopher Bernard Mandeville thought that only the slowly accumulated knowledge coming from experience can provide answers to such questions. Mandeville' views inspired us that, when we construct and improve the responsibility mechanism, we had better centralized the public's participation and wisdom.

Public service responsibility mechanism has a positive significance to transformation of the government function and establishment of responsible government. It is related to the issues that in which specific aspects the government performs its function, with its essence to refine government responsibility initiative. It also contains the spirit of public administration, combined with a moral mechanism to achieve the responsibility, releasing autonomy and trust of government officials, to consolidate the external constraint of strong mechanism against legal rules and regulations. The ultimate guide of public service responsibility mechanism is a perfect dynamic mechanism.

Therefrom, to focus on the correctness of the purpose and the means of public service responsibility mechanism, and public service results favorable combination of efficacy evaluation criteria, will be reasonable alternative standard to promote and pursue a long-term co-efficiency. Improvement of public service responsibility mechanism will to the maximum extent achieve the goal of efficiency and equity, instrumental rationality and value rationality.

\section{Plight OF ChinA's PUblic SERVICE ReSPONSIBILITY MECHANISM}

\section{A. Institutional Weaknesses}

Modern public service system is a complex formed from the rational combination of national mechanisms, social mechanisms and market mechanisms, which is based on the fundamental rights of citizens. From this definition, it indicates that public service system is closely related to the 
political system, administrative system, social system and the legal system of a country.

Before reform and opening up, China's public service system is basically a twin thing under the planned economy; while after the reform and opening up, public service system in different historical periods have been changed. From the view of existing central-local relations, the division of public services is not clear, and even very irregular. If this situation does not change soon, Public service system will be difficult to set up. Market economy has brought difficulties to the distribution of social responsibility, because government should not only deal with the contradictions between the own distribution and social distribution, but also deal with the contradiction between the government and the market, political responsibility and economic responsibility.

\section{B. Legal Barriers}

Absence of the rules in public service responsibility governance is also one plight of china's public service responsibility mechanism. China's government administration and public service management is highly correlated to politics, with administrative responsibility and political responsibility indistinguishable. Accountability is no clear legal provisions and rules-based, thus political conventions, chief's will and other factors will affect the responsibility and accountability. In the determination of liability, execution and accountability, the judicial authorities are difficult to get rid of the political, administrative intervention, and sometimes even become a political dependency. Some scholars believe corruption of public China's administration staff has a great relevance with the existing law system. The existing law system presents a hybrid, vague, overlapping characteristics in different public behavior specifications and processing, evolving into simplification or dogmatic processing. Such dogmatic processing mode not only leads to regardless of party in practice, but also to a great extent weaken the guidance and teaching function of legal norms, and finally makes responsibility mechanism hard to implement.

\section{Concept Limits}

Because of the lack of theoretical knowledge or skill, some cadres sometimes make mistakes in administrative practice or public service management. Due to the lack of relevant knowledge and theory, coupled with the misunderstanding of the public service, managers usually copy the Western national public service mechanism. In real life, there are no free products or services. Resource scarcity determines any services or products are a cost. As for public services, it is just relatively inexpensive, or the costs come from indirect payment by the taxpayer. Therefore, In this sense, there is essentially no difference between pure public services and quasi-public service.

Some government official's irresponsible current phenomenon still exists to varying degrees. Among them, executive power system, legal system of government responsibility and unspoken rule to gain personal gain and other issues, are main practical reasons resulting in lack of responsibility. Government should investigate the officialdom unspoken rule, and then refine the concept and responsibility attitude of government officials from unspoken rules. As one kind of officialdom common problem, there are cultural concepts behind unspoken rules. Only dispel the corresponding concept culture and improve the modern government responsibility idea can reduce the reality of lack of responsibility. However, Chinese government officials have held stubborn concept to control people. With the improvement of Social environment and public services, officials have to adopt a new approach to strengthen management and communication, to gain public services object's acceptation, approval and support, so that achieve better public service effect.

\section{CHINA's PUBLIC SERVICE RESPONSIBILITY MECHANISM CONSTRUCTION COUNTERMEASURES}

\section{A. Localization Innovation}

China's public service system is basically learning from western public administration practice and public service theory. Under the circumstances that there is a big gap between china's public service theory and the western countries, the positive study and the introduction is very necessary, which is not also the need to promote our country's practice of public service, but also the effective way to pursue the development of western public service. However, in order to apply the western public service theory into China's public service practice, first we need to analyze the localization condition thoroughly. It requires from two aspects of theory and practice to promote the localization of innovation of china's public service theory, so that solve the new problems and new contradictions in the development of public service in China.

Our country is a developing country, a social morphology that from low-level productive forces and inadequate market economy agriculture country towards higher productive forces and fuller market economy industrial country. This social morphology determines that the creation and development of our public services responsibility mechanism cannot be divorced from the reality condition of China. Therefore, for construction of public service responsibility mechanism, localization innovation is an inevitable choice. Specifically, there are two organically associated pathways: one is to make in-depth analysis of contemporary China's specific public service environment, so as to achieve combination of public service theory and China's practice; another is to study public service practice of contemporary Chinese social background, so as to achieve connection of public service theory and china's practice.

\section{B. Responsible Person Remodeling}

Improvement of responsible person and institutional mechanisms is fundamental condition to ensure citizens' rights and promote the comprehensive development of the modern state. Public services are the main areas of public administration, and the overall development of society and protection of the quality of all citizens' life is inseparable from the overall progress of a country's public services. Therefore, responsible person and responsibility mechanism should become urgent and important issues in our country. The status quo and future development of China's Public administration and public services will necessarily fall on 
remodeling and practice of responsible person and responsibility mechanism.

\section{CONCLUSION}

In order to set up China's responsible person and responsibility mechanism, we not only need to understand formative and hysteresis of various attitudes and behaviors that is not conducive to the public service responsibility mechanism to achieve, but also prevent those attitudes and behaviors from boycotting and sabotaging remodeling and practice of responsible person and responsibility mechanism.

\section{REFERENCES:}

[1] Mulgan, Richard, Comparing Accountability in the Public and Private Sectors[J]. Australian Journal of Public Administration, 2000 (1): 12.

[2] Lipsky M. Street-Level Bureaucracy, 30th Ann. Ed.: Dilemmas of the Individual in Public Service[M]. Russell Sage Foundation, 2010.

[3] Ning C A O X Z. The Analysis about the Power-responsibility Mechanism of Multiple Participators in the Crisis Management [J]. Chinese Public Administration, 2004, 7: 028.

[4] Friedman M. The social responsibility of business is to increase its profits[M]. springer berlin heidelberg, 2007.

[5] Nahmias E, Coates D J, Kvaran T. Free will, moral responsibility, and mechanism: Experiments on folk intuitions[J]. Midwest Studies in Philosophy, 2007, 31(1): 214-242.

[6] Paul S. Accountability in public services: exit, voice and control[J]. World Development, 1992, 20(7): 1047-1060. 